\title{
ANALISIS KEMISKINAN DAN PENGELUARAN NON-PANGAN PENDUDUK JAWA BARAT
}

\section{POVERTY AND NON-FOOD SPENDING ANALYSIS OF POPULATION IN WEST JAVA}

\author{
Trisna Subarna \\ Peneliti Badan Perencanaan Pembangunan Provinsi Jawa Barat \\ Jalan Ir. H. Juanda No. 287, Bandung \\ E-mail: mjlk_trisna@yahoo.co.id \\ Diterima: 2 Oktober 2012; direvisi: 7 November 2012; disetujui: 10 Desember 2012
}

\begin{abstract}
Abstrak
Masyarakat maju akan cenderung memiliki pengeluaran non-makanan yang lebih tinggi daripada pengeluaran untuk makanan, seperti untuk pendidikan, kesehatan, dan hiburan. Analisis ini bertujuan untuk mengetahui tingkat kesejahteraan dan strategi penanggulangan masyarakat miskin di Jawa Barat. Hasil analisis menunjukkan: (1) Tingkat kemiskinan di Jawa Barat berada di bawah tingkat kemiskinan nasional yaitu 11,27\% sedangkan tingkat kemiskinan Nasional 13,33\%. (2) Dibanding dengan Provinsi lain yang penduduknya tertinggi di Indonesia (Jawa Timur dan Jawa Tengah) persentase penduduk miskin di Jawa Barat lebih rendah, (3) Penduduk miskin di Jawa Barat pada tahun 2007 sebesar 13,55\%, tahun 2010 sebesar $11,27 \%$ atau dalam waktu 3 tahun terjadi penurunan penduduk miskin sebesar 2,27\% atau berkurang sebanyak 687.000 orang. (4) Rata-rata pengeluaran per kapita, penduduk Jawa Barat perbulan pada tahun 2011 sebesar Rp 561.837, dengan porsi penggunaan untuk makanan 51,77\%, dan nonmakanan 48,23\%, kondisi ini menunjukkan masih rendahnya tingkat kesejahteraan masyarakat Jawa Barat. Implikasi dari hasil analisi ini adalah; (1) Penanggulangan kemiskinan difokuskan pada upaya menumbuhkan budaya ekonomi produktif, (2) Perlu pemahaman berbagai pihak tentang penyebab kemiskinan, sehingga program pembangunan yang ada tidak didasarkan pada isu-isu kemiskinan yang penyebabnya berbeda-beda secara lokal.
\end{abstract}

Kata kunci: kemiskinan, pengeluaran non-pangan, strategi, kesejahteraan.

\begin{abstract}
Advanced community will tend to have higher non-food spending food spending, includes education, health, and entertainment. This analysis aims to determine the level of the welfare and poverty coping strategies in West Java. The analysis showed: (1) The poverty rate of West Java (11.27\%) was lower than the national poverty rate of $13.33 \%$. (2) Compared with other provinces having the highest population in Indonesia (East Java and Central Java), percentage of poor population in West Java were lower, (3) Within three years (2007-2010) the poor in West Java was steadily decreased from 13.55\% in 2007 to 11, $27 \%$ in 2010 (687. 000 people). (4) Average spending of West Java population per capita, per month in 2011 was Rp 561,837, with a portion of the use of 51.77\% for food and non-food $48.23 \%$, indicated that the low level of welfare of the people condition in West Java. The implications of the results of this analysis were: (1) Poverty alleviation focused on growing productive economic culture, (2) It should be an understanding of the various parties about the causes of poverty so that the development program was not based on the issues that cause poverty vary locally

Keywords: poverty, non-food expenditures, strategy, welfare.
\end{abstract}

\section{PENDAHULUAN}

Kesejahteraan masyarakat diantaranya ditentukan oleh tingkat kemiskinan yang dipengaruhi oleh tingkat pendapatan dan pola penggunaannya, yang berhubungan dengan tingkat pedapatan pola konsumsi pangan dan non-pangan (Arifin dan Simatupang, 1988). Masyarakat berpendapatan rendah akan mengalokasikan pendapatannya sebagian besar untuk memenuhi kebutuhan bahan pangan dibandingkan bahan non-pangan, semakin tinggi pengeluaran non-makanan mengindikasikan adanya perbaikan kesejahteraan penduduk (Hardjana, 1994),
Hasil penelitian Sari Novita dan Fardianah Mukhyar (2011), Rachman dan Wahida (1998), Suryana dkk. (1988) menyatakan bahwa komposisi pengeluaran rumah tangga dapat dijadikan ukuran guna menilai tingkat kesejahteraan ekonomi penduduk, semakin rendah persentase pengeluaran untuk pangan terhadap total pengeluaran makin membaik tingkat perekonomian penduduk. Sebaliknya, semakin besar pangsa pengeluaran pangan semakin kurang sejahtera rumahtangga yang bersangkutan Dalam kondisi pendapatan terbatas maka pemenuhan kebutuhan makanan akan didahulukan, sehingga pada kelompok masyarakat 


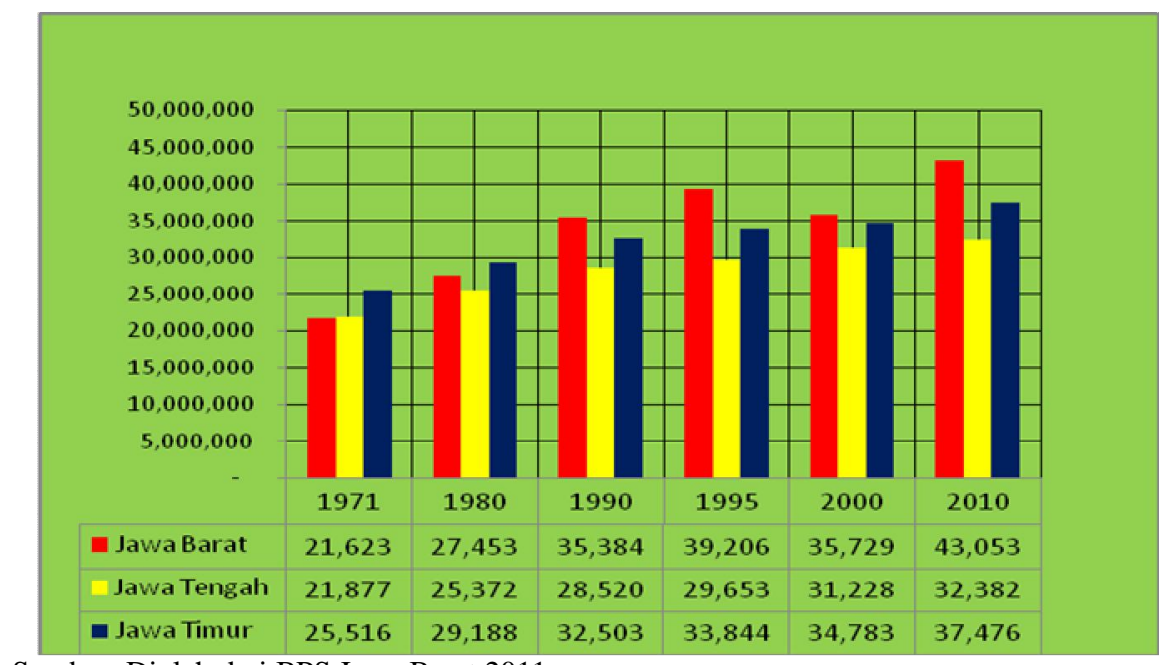

Sumber: Diolah dari BPS Jawa Barat 2011.

Gambar 1. Perbandingan Jumlah Penduduk Tiga Provinsi Terbesar di Indonesia.

yang berpendapatan rendah akan terlihat sebagian besar pendapatan mereka digunakan untuk membeli pangan (Sukirno 2000).

Berdasarakan uraian di atas, maka struktur pengeluaran rumah tangga dapat dijadikan salah satu indikator untuk melihat tingkat kesejahteraan rumah tangga, Analisis ini bertujuan untuk mengetahui kabupaten/kota yang berada pada berbagai strata kesejahtreraan dibanding dengan jumlah penduduk.

\section{METODE PENELITIAN}

Metode yang digunakan dalam penelitian ini menggunakan pendekatan kualitatif (mix method), metoda analisis campuran dengan teknik pengumpulan data skunder yang berasal dari dokumen, laporan, dan lieratur yang berkaitan dengan kemiskinan dan pengeluaran masyarakat di Jawa Barat. Data primer diperoleh dari Focus Group Discussion (FGD) dengan peserta dari Organisasi Perangkat Daerah Provinsi Jawa Barat dan lembaga lain yang berhubungan dengan kemiskinan yaitu: perencana dan peneliti Bappeda sebanyak 4 orang, Badan Pemberdayaan Masyarakat Desa 4 orang, Dinas Enegi dan Sumberdaya Mineral 2 orang, Himpunan Kerukunan Tani Indonesia (HKTI) Jawa Barat 1 orang, dan lembaga penelitian Unpad 2 orang, serta Kamar Dagang dan Industri 1 orang sehingga jumlah peserta FGD sebanyak 14 orang. Data yang terkumpul dianalisis dengan tabulasi silang dan dijelaskan secara deskriptif.

\section{HASIL DAN PEMBAHASAN}

\section{Kondisi Penduduk Jawa Barat Di Tingkat Nasional}

Hasil sensus penduduk 2010 menunjukan jumlah penduduk Indonesia sebanyak 237.556.363 orang dengan komposisi penduduk laki-laki sebesar
119.507.580 orang dan perempuan 118.048.783 orang. Jumlah penduduk terbesar berada di Provinsi Jawa Barat sebesar 43,02 juta orang $(18,11 \%)$, posisi kedua adalah Provinsi Jawa Timur sebesar 37,8 juta orang $(15,78 \%)$ dan ketiga terbesar berada di Jawa Tengah 32,38 juta orang $(13,63 \%)$ seperti pada Gambar 1.

Jumlah penduduk yang besar ini membawa persoalan bagi pemerintah Provinsi Jawa Barat dalam meningkatkan kesejahteraan penduduknya, serta berimplikasi yang luas terhadap lingkungan, sektor pembangunan, dan ketahanan pangan, terutama dalam mengendalikan kemiskinan.

Tingkat kemiskinan di Jawa Barat berada pada posisi 15 nasional, lebih rendah dibanding dengan tingkat kemiskinan nasional $(13.33 \%$ pada tahun 2010). Jumlah penduduk miskin di Jawa Barat pada tahun 2010 sebesar $11,27 \%$ atau 4.848 .560 jiwa. Penduduk miskin ini diperkirakan akan terus meningkat di tahun-tahun mendatang terutama di daerah-daerah yang penduduknya bermata pencaharian buruh, nelayan dan pertanian. Dibanding dengan provinsi lain (Jawa Timur dan Jawa Tengah) dengan jumlah penduduk yang tertinggi di Indonesia ternyatapersentase penduduk miskin di Jawa Barat lebih rendah (Gambar2).

Kondisi di atas menunjukkan walaupun dengan penduduk yang lebih besar, pemerintah Provinsi Jawa Barat lebih dapat mengendalikan tingkat kemiskinannya dibanding dengan provinsi lain yang jumlah penduduknya tertinggi di Indonesia. Hal ini terlihat pada perkembangan penduduk miskin di Jawa Barat pada akhir tahun RPJMD 2003-2007 sebesar 13,55\%, dan dalam kurun waktu mid-term RPJMD tahun 2008-2013 sampai dengan tahun 2010 sebesar $11,27 \%$ atau dalam waktu 3 tahun pelaksanaan RPJMD turun $2,27 \%$ atau jumlah penduduk miskin berkurang sebesar 687.000 orang (Gambar 3). 


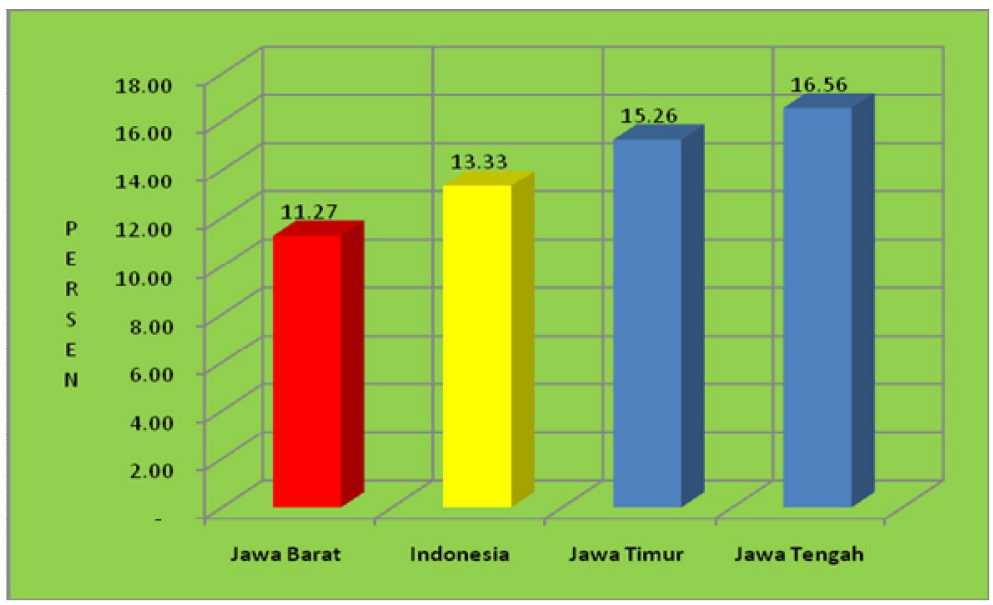

Sumber: Diolah dari BPS Jawa Barat 2011.

Gambar 2. Persentase Penduduk Miskin di Tiga Provinsi dengan Jumlah Penduduk Terbanyak.

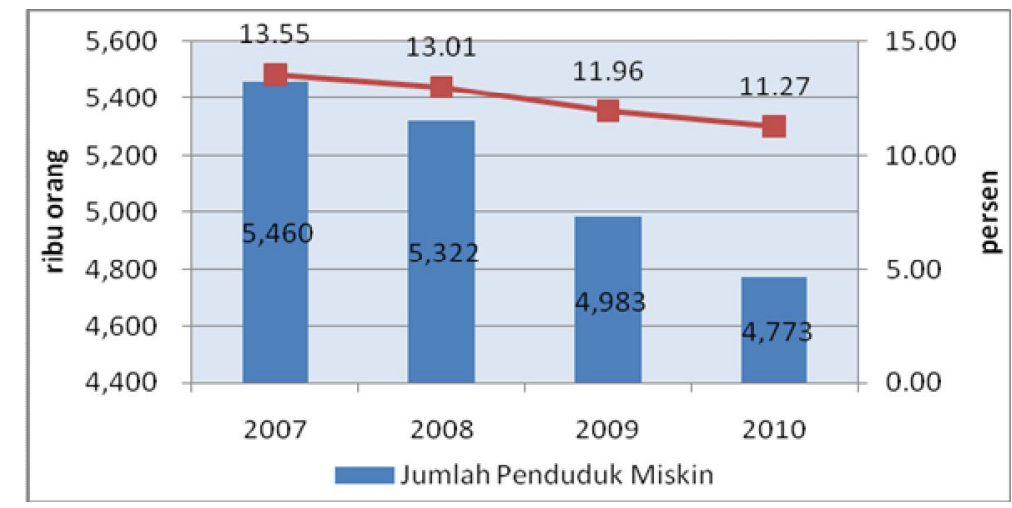

Sumber data : BPS Provinsi Jawa Barat, 2007,2008,2009, 2010,2011 diolah.

Gambar 3. Perkembangan Tingkat Kemiskinan dan Jumlah Penduduk Miskin Tahun 2007-2010, Provinsi Jawa Barat.

Berdasarkan data BPS Provinsi Jawa Barat (2011) tingkjat kemiskinan teringgi berada di Kota Tasikmalaya (23,55\%), Kabupaten Cirebon (18,22\%), Kabupaten Indramayu (17,99\%), dan Kabupaten Majalengka 17,12\%), sedangkan tingkat kemiskinan terendah berada di Kota Depok (2,93\%), Kabupaten Bandung Barat (4,5\%), dan Kota Bandung ( 4,5\%). Seperti terlihat pada Gambar 4.

\section{Pengeluaran Rumah Tangga Penduduk Jawa Barat}

Pengeluaran merupakan indikator yang penting dalam melihat kesejahteraan masyarakat. Pengeluaran seseorang yang besar menunjukkan tingkat daya beli orang tersebut besar. Penduduk dengan pengeluaran besar maka kebutuhan penduduk tersebut sebagian besar terpenuhi. Dengan terpenuhi kebutuhan hidupnya maka secara umum kesejahteraan akan meningkat. Perkembangan tingkat kesejahteraan juga dapat diamati berdasarkan perubahanpersentase pengeluaran yang dialokasikan untuk non-makanan, dimana semakin tinggipersentase pengeluaran non- makanan dapat mengindikasikan adanya perbaikan tingkat kesejahteraan.

Ernest Engel, dalam Salvatore (2006), mengemukakan bahwa bila selera tidak berbeda makapersentase pengeluaran untuk pangan akan menurun dengan meningkatnya pendapatan. Oleh karena itu komposisi pengeluaran rumah tangga dapat dijadikan ukuran guna menilai tingkat kesejahteraan ekonomi penduduk, makin rendahpersentase pengeluaran untuk pangan terhadap total pengeluaran makin membaik tingkat perekonomian penduduk. Sebaliknya, semakin besar pangsa pengeluaran pangan semakin kurang sejahtera rumah tangga yang bersangkutan.

Tahun 2010, porsi penggunaan pengeluaran masyarakat Jawa Barat digunakan untuk makanan $51.77 \%$, dan non-makanan 48.23\% (Gambar 5), kondisi ini menunjukkan masih tingginya pengeluaran untuk pangan yang menunjukkan masih rendahnya tingkat kesejahteraan masyarakat Jawa Barat.

Kemiskinan tidak terlepas dari pola penerimaan dan pengeluaran, pengeluaran akhir 


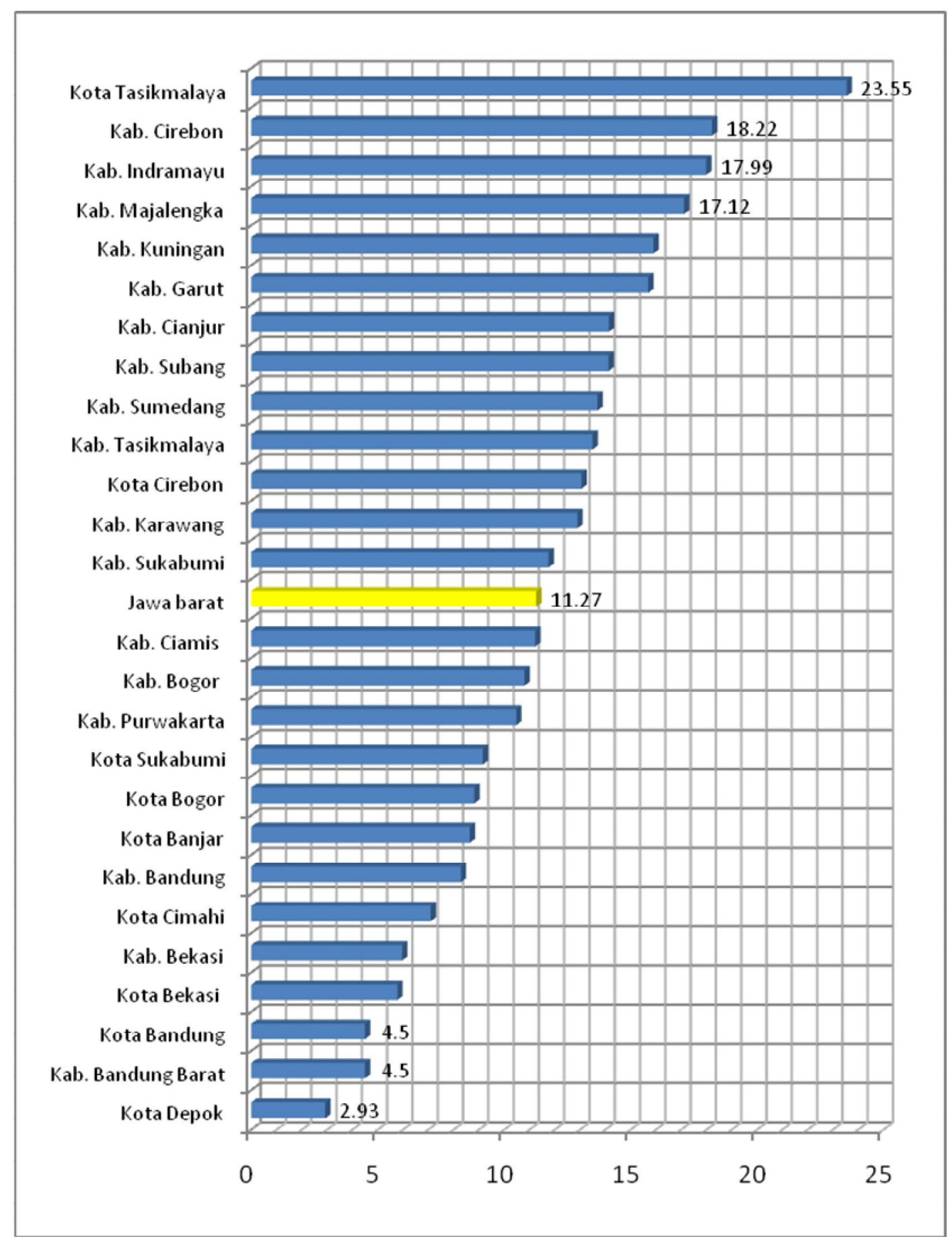

Sumber: Pusdalisbang Bappeda Provinsi Jawa Barat 2012 diolah.

Gambar 4. Tingkat Kemiskinan Kabupaten Kota di Jawa Barat Tahun 2010 (\%).

meliputi seluruh pengeluaran yang dilakukan oleh anggota rumah tangga suatu penduduk, baik pengeluaran untuk makanan maupun bukan makanan yang meliputi pengeluaran untuk sandang, pendidikan, perumahan, pengeluaran kesehatan, barang-barang tahan lama, rekreasi dsb. Rata-rata pengeluaran per kapita, penduduk Jawa Barat perbulan pada tahun 2011 tercatat sebesar Rp 561.837. Pengeluaran tertinggi di Kota Bandung sebesar Rp 989.657 dan terendah di Kab. Tasikmalaya Rp 340562. Terdapat tujuh Kota dan tiga Kabupaten yang berada di atas rata-rata Jawa Barat total pengeluarannya, dan terdapat satu kota dan 15 Kabupaten yang berada di bawah rata-rata Jawa Barat, (Gambar 6).

Ernest Engel, dalam Salvatore (2006), Teori Engel's yang menyatakan bahwa: "Semakin tinggi tingkat pendapatan keluarga semakin rendah presentasi pengeluaran untuk konsumsi makanan”. Berdasarkan teori klasik ini, maka keluarga bisa dikatakan lebih sejahtera bila presentasi pengeluaran 


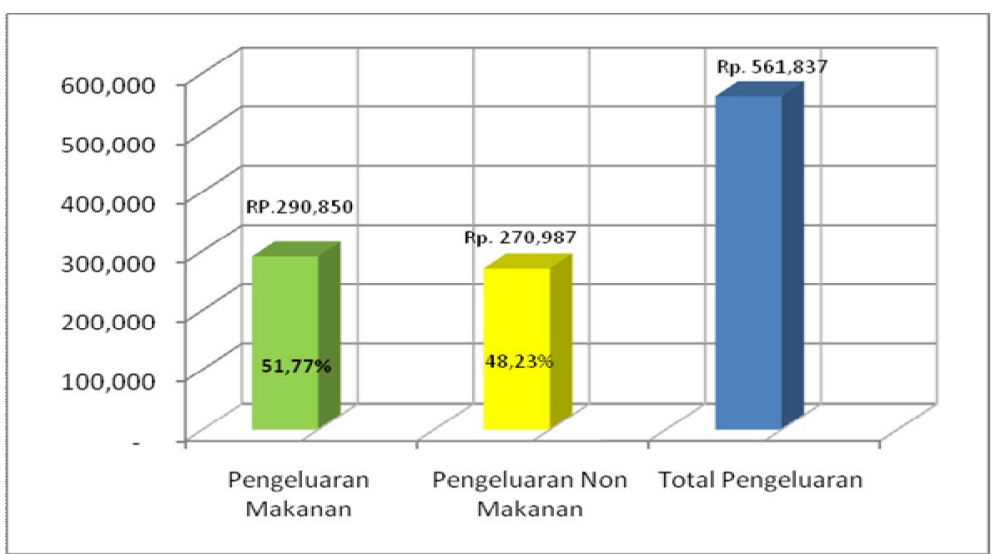

Sumber data :BPS Provinsi Jawa Barat 2011 diolah.

Gambar 5. Pola Pengeluaran Penduduk Jawa Barat Tahun 2010.

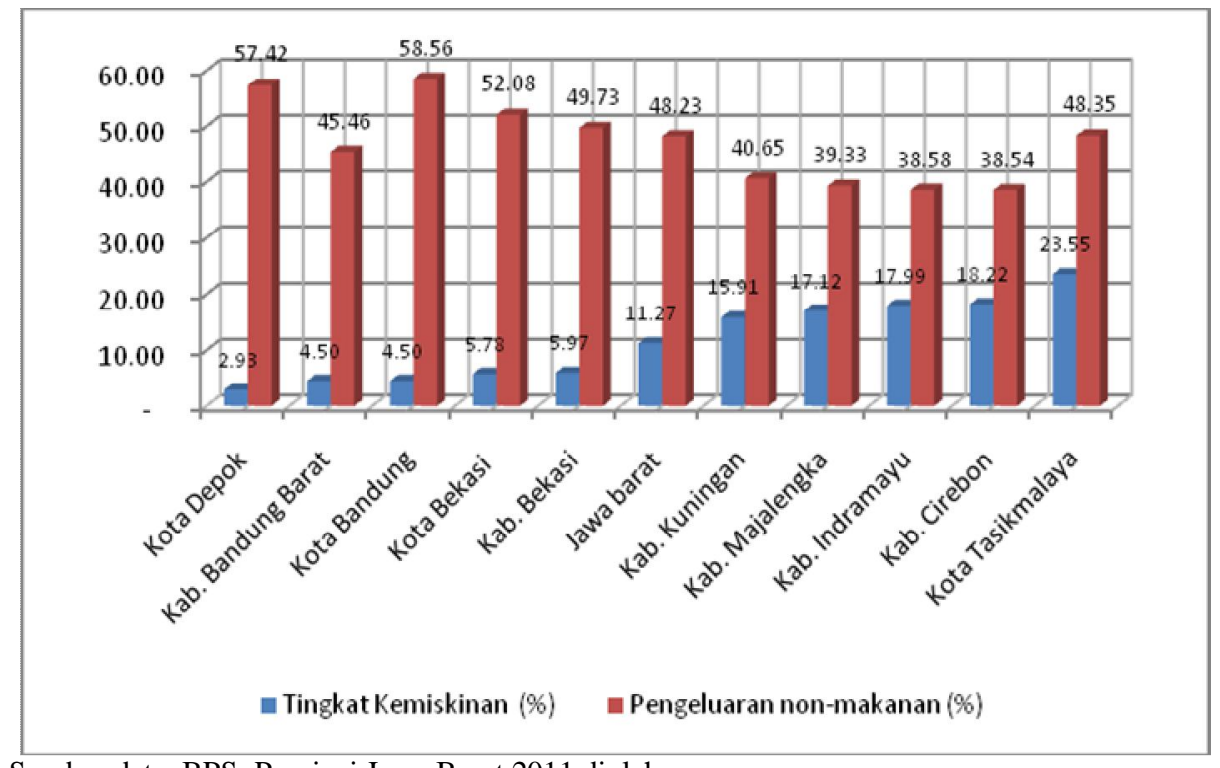

Sumber data :BPS Provinsi Jawa Barat 2011 diolah.

\section{Gambar 6. Tingkat Kemiskinan Dan Pengeluaran Non-Makanan 5 Kabupaten/Kota} Tertinggi dan Terendah di Jawa Barat (dalam \%).

untuk makanan jauh lebih kecil dari presentasi pengeluaran yang untuk bukan makanan. Artinya proporsi alokasi pengeluaran untuk pangan akan semakin kecil dengan bertambahnya pendapatan keluarga, karena sebagian besar dari pendapatan tersebut dialokasikan pada kebutuhan non pangan.

Gambar 5 di atas menunjukkan pengeluaran non-makanan untuk penduduk kabupaten/kota dengan tingkat kemiskinan rendah lebih besar di banding dengan kabupaten/kota dengan tingkat kemiskinan yang lebih tinggi. Untuk penduduk Jawa Barat persentase untuk pengeluaran makanan 51,77\%, sedangkan untuk non-makanan adalah 48,23\% . Lebih besarnya persentase pengeluaran penduduk untuk makanan dibandingkan non-makanan ini mencerminkan bahwa tingkat kesejahteraan penduduk di Jawa Barat masih relatif rendah.
Dari uraian diatas dapat disimpulkan bahwa pendapatan mempunyai peranan penting dalam mempengaruhi pengeluaran konsumsi masyarakat, baik itu konsumsi barang tidak tahan lama, barang tahan lama, dan jasa. Hal inin sesuai dengan pendapat Keban (1995) dalam Khairil Anwar (2012) di dalam analisisnya dinyatakan bahwa suatu keluarga tergolong miskin kalau ratio pengeluaran untuk makanan terhadap total pengeluaran melebihi $75 \%$.

\section{Strategi Menanggulangi Kemiskinan}

Hasil diskusi melalui FGD dalam rangka menanggulangi kemiskinan diperoleh strategi sebagai berikut:

1. Pola inkubasi bisnis.

Merupakan pola penanggulangan kemiskinan berdasarkan skema pendampingan melalui proses inkubasi bisnis pada unit-unit kegiatan 
usaha baik melalui skema program kegiatan dari pemerintah maupun melalui skema kegiatan pemerintah kerjasama, swasta (pelaku usaha) dengan kelompok sasaran masyarakat miskin dan hampir miskin.

2. Pola penyediaan lapangan kerja.

Merupakan pola penyediaan lapangan kerja baik berupa kegiatan padat karya, maupun kegiatan yang dapat menyerap tenaga kerja berbasis pengetahuan dan keterampilan yang diselenggarakan oleh Pemerintah maupun swasta dengan kelompok sasaran masyarakat hampir miskin, masyarakat miskin dan masyarakat sangat miskin.

3. Pola pemenuhan kebutuhan dasar.

Merupakan pola penanggulangan kemiskinan yang berorientasi kepada pemenuhan kebutuhan dasar masyarakat miskin meliputi kebutuhan dasar pangan, kesehatan, pendidikan, pekerjaan, perumahan, air bersih, pertanahan, sumber daya alam dan lingkungan hidup, rasa aman dari perlakuan atau ancaman tindakan kekerasan serta berpartisipasi dalam kehidupan sosial politik. Adapun input yang dilaksanakan berupa penyediaan, fasilitasi maupun pendukungan untuk memenuhi hak-hak dasar tersebut, dengan kelompok sasaran masyarakat hampir miskin, masyarakat miskin dan masyarakat sangat miskin.

4. Pola perlindungan dan jaminan sosial.

Merupakan pola untuk mengatasi kondisi darurat bagi masyarakat miskin dan masyarakat sangat miskin dalam upaya mengatasi berbagai permasalahan yang menimpa masyarakat miskin hingga kelompok sasaran memasuki fase recovery.

5. Pola peduli masyarakat miskin jawa barat.

Merupakan pola penanggulangan kemiskinan melalui peran aktif masyarakat dan swasta dalam penanggulangan kemiskinan, baik secara sistemik maupun parsial dengan pola asuh dengan kelompok sasaran masyarakat hampir miskin, masyarakat miskin dan masyarakat sangat miskin.

Salah satu program pembangunan di Indonesia, termasuk di Jawa Barat yang senantiasa menjadi isu strategis adalah pengentasan kemiskinan yang secara otomatis akan berimplikasi pada peningkatan kesejahteraan masyarakat. Pengentasan kemiskinan hanya menggunakan pendekatan ekonomi yang bersifat materialistik yang didasari oleh dua faktor utama yaitu (Lipi Ahmad, 2011);

1. Penanggulangan kemiskinan cenderung berfokus pada upaya penyaluran bantuan sosial seperti jaring pengaman sosial dan beras untuk rakyat miskin, padahal seharusnya diorientasikan pada upaya menumbuhkan budaya ekonomi produktif

2. Kurangnya pemahaman berbagai pihak tentang penyebab kemiskinan, sehingga program pembangunan yang ada tidak didasarkan pada isu-isu kemiskinan yang penyebabnya berbedabeda secara lokal

Agar mencapai keberlanjutannya, program penanggulangan kemiskinan dengan pendekatan ekonomi yang bersifat material dan jangka pendek, perlu diimbangi dengan strategi pengentasan kemiskinan dengan menggunakan pendekatan kependudukan, meskipun hasilnya baru bisa dirasakan dalam jangka panjang. Yang dimaksud adalah penanggulangan kemiskinan berdasarkan pada sumber kemiskinan itu sendiri. Sumber kemiskinan adalah jumlah penduduk yang tinggi dan kualitas hidup masyarakat yang rendah. Sebagaimana disepakati dunia internasional bahwa tolak ukur kualitas hidup masyarakat adalah IPM (indeks pembangunan Manusia), yaitu kualitas pendidikan, kualitas kesehatan dan kualitas ekonomi. Oleh karena itu, penanggulangan kemiskinan sudah saatnya berdasarkan pada langkah langkah strategis berupa menekan laju pertumbuhan penduduk dan peningkatan kualitas hidup masyarakat. Semakin tinggi jumlah penduduk akan menyebabkan bertambahnya beban pembangunan, berkurangnya ketersediaan lahan dan lapangan pekerjaan, meningkatnya pengangguran, dan lain-lain (Lipi Ahmad, 2011).

\section{SIMPULAN}

Tingkat kemiskinan di Jawa Barat berada pada posisi 15 Nasional, yaitu $11,27 \%$, pada posisi tersebut lebih rendah dibanding dengan tingkat kemiskinan Nasional yaitu $13.33 \%$. Perkembangan penduduk miskin di Jawa Barat pada tahun 2007 sebesar 13,55\%, dan tahun 2010 sebesar 11,27 perrsen atau dalam waktu 3 tahun pelaksanaan RPJMD turun $2,27 \%$, atau jumlah penduduk miskin berkurang sebesar 687.000 orang.

Rata-rata pengeluaran per kapita, penduduk Jawa Barat perbulan pada tahun 2011 tercatat sebesar Rp 561.837. Pengeluaran tertinggi di Kota Bandung sebesar Rp 989.657 dan terendah di Kab. Tasikmalaya Rp 340562. Pada tahun 2010 porsi penggunaan pengeluaran masyarakat Jawa Barat yang digunakan untuk makanan $51.77 \%$, dan non-makanan 48.23\%, kondisi ini menunjukkan masih tingginya pengeluaran untuk pangan yang menunjukkan masih rendahnya tingkat kesejahteraan masyarakat Jawa Barat

Penanggulangan kemiskinan harus difokuskan pada upaya menumbuhkan budaya ekonomi produktif. Perlu pemahaman berbagai pihak tentang penyebab kemiskinan, sehingga program pembangunan yang ada tidak didasarkan pada isu-isu kemiskinan yang penyebabnya berbeda-beda secara local.

\section{DAFTAR PUSTAKA}

Ahmad, Lipi. 2011. Kesejahteraan, Kemiskinan dan Program KB di Jawa Barat http://jabar.bkkbn.go.id/Lists/Artikel/DispForm.a 
spx?ID=588\&ContentTypeId $=0 x 01003$ DCABA

BC04B7084595DA364423DE7897

Anwar, Khairil 2012. Beberapa Hasil Penelitian tentang Konsumsi. http://khairilanwarsemsi.blogspot. com/2011/12/beberapa-penelitian-tentangkonsumsi.html

Arifin, M dan P. Simatupang. 1988. Pola Konsumsi dan Kecukupan Kalori dan Protein di Pedesaan Sumatera Barat dalam Prosiding Patanas Perubahan Ekonomi Pedesaan Menuju Struktur Ekonomi Berimbang. Pusat Penelitin Agro Ekonomi

BPS Provinsi Jawa Barat. 2007. Jawa Barat dalam Angka Tahun 2006.

BPS Provinsi Jawa Barat. 2008. Jawa Barat dalam Angka Tahun 2007.

BPS Provinsi Jawa Barat. 2009. Jawa Barat dalam Angka Tahun 2008.

BPS Provinsi Jawa Barat. 2010. Jawa Barat dalam Angka Tahun 2009.

BPS Provinsi Jawa Barat. 2011. Jawa Barat dalam Angka Tahun 2010.

BPS Provinsi Jawa Barat. 2012. Jawa Barat dalam Angka Tahun 2011.

Hardjana, A. 1994. Orientasi Perilaku Konsumsi tentang Masalah Pangan dan Gizi dari Sumber Hayati Kelautan. Risalah Widyakarya Pangan dan Gizi. Jakarta: LIPI.

Novita, Sari dan Fardianah Mukhyar 2011. Kajian: Pola Pengeluaran Pangan Rumah Tangga Petani Padi Sawah di Kabupaten Banjar Kalimantan Selatan Jurnal Agribisnis Perdesaan. Volume 01 Nomor 04 Desember 2011.

Rachman, H.P.S dan Wahida. 1998. Dinamika Pola Pengeluaran dan Konsumsi Rumah Tangga serta Prospek Permintaan Pangan dalam Dinamika Ekonomi Pedesaan: Perubahan Struktur Pendapatan, Ketenagakerjaan dan Pola Konsumsi Rumah Tangga. Bogor: Kerjasama Puslit Sosial Ekonomi Pertanian dengan Ford Foundation.

Rachman, H.P.S. dan S.H. Suhartini. 1996. Ketahanan Pangan Masyarakat Berpendapatan Rendah di Jawa Barat dan Nusa Tenggara Barat. Jurnal Agro Ekonomi: 15 (2)

Sadono, Sukirno. 2000. Pengantar Teori Mikroekonomi. Jakarta: PT. Raja Grafindo Persada.

Salvatore, D. 2006. Mikroekonomi. Edisi ke-4. Jakarta: Erlangga.

Suryana, A, B. Rachman dan P.U. Hadi. 1988. Pola Pengeluaran untuk Konsumsi di Pedesaan Jawa Barat dalam Prosiding Patanas Perubahan Ekonomi Pedesaan Menuju Struktur Ekonomi Berimbang. Pusat Penelitin Agro Ekonomi. 
250 | Jurnal Bina Praja | Volume 4 No. 4 Desember 2012 |243 - 250 